\title{
Pengaruh Pemberian Pupuk Kompos Dan Pupuk Green Tonik Terhadap Pertumbuhan Dan Hasil Tanaman Cabai Rawit (Capsicum frustescens L) Varietas Bhaskara
}

\section{The Influence Of Compost Fertilizer And Green Tonic Fertilizer To The Growth And Results Of Rawit Chili Plants (Capsicum frustescens L) Bhaskara Varieties}

\author{
Ndaru Kuncoro ${ }^{1}$, Tutik Nugrahini ${ }^{2}$, Mahdalena $^{2}$ \\ ${ }^{1}$ Alumni Program Studi Agroteknologi, Fakultas Pertanian, Universitas Widya Gama Mahakam \\ ${ }^{2}$ Tenaga Pendidik Program Studi Agroteknologi, Fakultas Pertanian, Universitas Widya Gama Mahakam \\ Jl. KH. Wahid Hasyim, Sempaja, Samarinda, Kalimantan Timur, Indonesia \\ email : kuncorondaru@gmail.com, tutiknugrahini@uwgm.ac.id,mahdalena@uwgm.ac.id
}

Diterima : 24 Agustus 2017 Disetujui : 13 Oktober 2017

\begin{abstract}
The Influence of Compost Fertilizer And Grenn Tonic Fertilizer On The Growth And Results Of Rawit Chili Plants (Capsicum frustescens L) Bhaskara Varieties. The purpose of this research is to know the response of the use of compost fertilizer, Green Tonik liquid fertilizer and the interaction between compost fertilizer and Green Tonik liquid fertilizer on the growth and yield of pepper plant. The study was carried out for approximately 4 months, starting from July to October 2015, the research site at Jl. Thoyib Hadiwijaya Sempaja Timur, North Samarinda, East Kalimantan Province. The study was carried out for approximately 4 months, starting from July to October 2015, the research site at Jl. Thoyib Hadiwijaya Sempaja Timur, North Samarinda, East Kalimantan Province. This research method used Randomized Block Design with $4 \times 4$ factorial analysis consisting of 3 replications. The first factor is compost $(\mathrm{k})$ consisting of 4 levels: $\mathrm{k0}$ : (control), $\mathrm{kl}: 50 \mathrm{~g} /$ polybag, $\mathrm{k2:} 100 \mathrm{~g} /$ polybag and $\mathrm{k3:} 150 \mathrm{~g} /$ polybag and second factor is Grenn Tonic ( $g$ ) which consists of 4 levels: g0: (control), g1: 1.5ml / liter of water, g2: $3 \mathrm{ml} /$ liter of water and $\mathrm{g} 3: 4.5 \mathrm{ml} /$ liter of water. The results of the compost fertilizer $(\mathrm{k})$ showed that the effect was very significant on the average height and diameter of the plants at the age of 27 days HST, 40 HST and 53 HST as well as the average of crop yields, the highest crop yield on the treatment $k 2$. The Green Tonic fertilizer treatment (g) showed that significantly affected the mean height and diameter of the plants at 27 days of HST, 40 HST and 53 HST as well as the average crop yield, the highest crop yield on treatment $\mathrm{g} 2$. In the second interaction treatment of compost $(k)$ and Green Tonic $(g)$ fertilizer had no significant effect on average of plant height increase, early age of flower, early age of harvest and fruit weight.
\end{abstract}

Keywords: Compost Fertilizer, Liquid Green Fertilizer Tonic and Chilli

\section{PENDAHULUAN}

Cabai rawit (Capsicum frustescens) termasuk salah satu komoditi hortikultura kelompok sayuran yang banyak diusahakan petani dalam berbagai skala usaha tani, karena mempunyai keungggulan komparatif dan kompetitif. Cabai rawit (C. frustescens) memiliki posisi yang penting dalam pola konsumsi makanan masyarakat Indonesia dan mempunyai prospek yang cukup cerah (Rukmana, 2006).

Keberhasilan dalam budidaya cabai rawit (C. frustescens) mengutamakan perbaikan teknologi, mulai dari pemilihan varietas, pembenihan, pemeliharaan tanaman, pemanenan hingga pasca panen (Rukmana, 2006).

Pemilihan varietas merupakan upaya awal dalam pembudidayaan tanaman cabai rawit ( $C$. frustescens) yang sangat mempengaruhi hasil produksi tanaman. Pemilihan variestas tanaman dilakukan dengan pertimbangan diantaranya ; dapat dipanen pada umur genjah, tahan terhadap serangan hama dan penyakit serta mampu beradaptasi pada lingkungan (Rukmana, 2006).

Pemeliharaan tanaman cabai rawit $(C$. frustescens) diantaranya pemupukan. Pemupukan merupakan upaya memenuhi kebutuhan unsur hara bagi tanaman. Kebutuhan unsur hara dapat dipenuhi dilakukan dengan cara melakukan pemupukan menggunakan pupuk organik (Lingga dan Marsono, 2013). Ditambahkan oleh Wiryanta (2012) bahwa pemupukan bertujuan untuk menambahkan unsur hara yang di butuhkan oleh tanaman sebab unsur hara yang terdapat dalam tanah tidak biasa di andalkan untuk memacu pertumbuhan tanaman cabai secara optimal.

Diwilayah Samarinda mempunyai spesefik tanah yang tergolong podsolik (ultisol). Menurut SoilTaxanomy USDA tanah ultisol merupakan tanah yang mengalami pelapukan terus menerus terhadap mineral liat yang membuat tanah menjadi liat (Anonim, 2013). Tanah liat merupakan tanah yang tidak memiliki dranase dan aerasi yang baik. Tanah yang tidak memiliki dranase dan aerasi yang baik 
mengakibatkan sistem perakaran tanaman terganggu sehingga penyerapan unsur hara bagi tanaman tidak terjadi secara optimal. Permasalahan dalam struktur tanah berupa tanah liat dapat dilakukanupaya penambahan bahan organik berupa pupuk organik. Dengan pemberian pupuk organik sifat fisik tanah yang keras akan menjadi gembur yang mengakibatkan akar tanaman dapat leluasa untuk mencari unsur hara dalam tanah, pupuk organik mempengaruhi sifat kimia dalam penyedian unsur hara dan pupuk organik dapat mempengaruhi sifat biologi tanah yaitu dapat memberikan sumber energi bagi jasad-jasad renik yang melakukan perombakan dalam tanah guna menjaga kesuburan tanah (Lingga dan Marsono, 2013).

Menurut Lingga dan Marsono (2013) berdasarkan asal pembuatannya pupuk terdiri dari 2 kelompok yaitu ; pupuk organik dan pupuk anorganik. Pupuk anorganik dibuat oleh pabrik dan berbahan bahan-bahan kimia sedangkan pupuk organik adalah pupuk yang berasal dari pelapukan bahan-bahan organik berupa sisa-sisa tanaman, fosil manusia dan hewan, kotoran hewan dan batu-batuan yang terbentuk dari tumpukan kotoran hewan selama ratusan tahun.

Pupuk organik dan pupuk anorganik mempunyai kelebihan dan kekurangan masing-

\section{BAHAN DAN METODE}

Penelitian dilaksanakan kurang lebih 4 bulan, mulai dari bulan Juli sampai dengan Oktober 2015, tempat penelitian di lahan J1. Thoyib Hadiwijaya Sempaja Timur, Samarinda Utara, Provinsi Kalimantan Timur. Bahan yang digunakan dalam penelitian ini adalah benih cabai rawit varietas Bhaskara,polybag $40 \times 40$ $\mathrm{cm}$, pupuk kompos, pupuk cair anorganik green tonik, top soil, pupuk kandang ayam, pestisida organik pestona, fungisida sistemik navito, sekam, pasir, plastik cocker dan air. Penelitian ini menggunakan Rancangan Acak Kelompok dengan analisis faktorial $4 \mathrm{x} 4$ yang terdiri dari 3 ulangan. Faktor pertama pupuk kompos (k)yang terdiri dari 4 taraf, yaitu : k0 ; (kontrol), k1 ; 50

\section{HASIL DAN PEMBAHASAN}

\section{Pengaruh Pupuk Kompos}

Berdasarkan hasil sidik ragam perlakuan pupuk kompos (k) menunjukkan bahwa berpengaruh sangat nyata terhadap rata-rata tinggi dan diameter tanaman pada umur 27 hari HST, 40 HST dan 53 HST serta rata-rata hasil tanaman. Namun tidak berpengaruh nyata masing dalam penggunaannya. Pupuk organik dihasilkan dari pelapukan sisa-sisa tanaman, hewan dan manusia yang mempunyai beberapa kelebihan antaranya ; memperbaiki struktur tanah, menaikkan daya serap tanah terhadap air, menaikkan kondisi kehidupan di dalam tanah dan sebagai sumber zat makanan bagi tumbuhan (Lingga dan Marsono) 2013).

Menurut hasil penelitian Susila dan Luthfyrakhman (2013) mendapatkan hasil bahwa perlakuan pupuk organik (pupuk kandang kotoran ayam petelur) dan pupuk anorganik (Urea 46\% N, KCL 60\% $\mathrm{K}_{2} \mathrm{O}$, SP $3636 \% \mathrm{P}_{2} \mathrm{O}_{5}$ ) berpengaruh terhadap bobot buah cabai per petak (kg). Ditambahkan lagi oleh Kaunang, dkk (2013) dari hasil penelitian bahwa pemupukan dengan menggabungkan antara pupuk organik dari feces ayam (bahan pembuat kompos) dan pupuk anorganik (Urea, SP36 dan KCL) lebih meningkatkan produksi tanaman jagung baik itu panjang tongkol, lingkar tongkol dan bobot pipilan kering.

Berdasarkan uraian di atas, maka dilakukan penelitian mengenai pengaruh pemberian pupuk kompos dan pupuk cair Green Tonik terhadap pertumbuhan dan hasil tanaman cabai (Capsicum frustescens).

g/polybag, k2 ;100 g/polybag dan k3 ; 150 $\mathrm{g} /$ polybag dan faktor kedua Green Tonik (g) yang terdiri dari 4 taraf, yaitu : g0 ; (kontrol), g1 ; 1,5ml/liter air, g2 ; $3 \mathrm{ml} /$ liter air, g3 ; 4,5 $\mathrm{ml} /$ liter air. Pelaksanaan penelitian meliputi : persiapan lahan, penyemaian benih, penanaman, pemasangan ajir, aplikasi perlakuan, pemeliharaan meliputi ; penyiraman, penyulaman, penyiangan dan panen. Pengambilan data pengambilan ; pertambahan tinggi tanaman, umur muncurl bunga dan berat buah. Data di analisis dengan menggunakan sidik ragam, apabila ada pengaruh maka dilakukan Uji lanjutan dengan menggunakan Uji Beda Nyata Terkecil ( BNT ) pada taraf 5\% untuk membandingkan dua rata-rata perlakuan.

terhadap umur awal muncul bunga dan waktu awal panen. Perlakuan pupuk kompos (k) sangat nyata berpengaruh terhadap rata-rata tinggi dan diameter tanaman pada umur 27 hari HST, 40 HST dan 53 HST serta rata-rata hasil tanaman. Penggunaan pupuk kompos memberikan pengaruh yang nyata terhadap fase vegetatif 
(tinggi tanaman dan diameter batang) dan fase generatif (hasil panen) pada tanaman cabai.

Rata-rata tinggi tanaman umur 27 hari HST, 40 HST dan 53 HST yang tertinggi pada perlakuan $\mathrm{k} 3$ secara berurutan menurut umur tanaman yaitu $23,62 \mathrm{~cm}, 46,82 \mathrm{~cm}$ dan $68,25 \mathrm{~cm}$ dan rata-rata tinggi terendah pada perlakuan $\mathrm{k} 0$ secara berurutan menurut umur tanaman yaitu $20,39 \mathrm{~cm}, 42,82 \mathrm{~cm}$ dan $60,59 \mathrm{~cm}$. Keadaan yang ada pada penelitian ini diduga bahwa kandungan unsur hara yang dikandung oleh pupuk kompos dapat menyediakan bagi kebutuhan tanaman. Hal ini sesuai dengan tulisan Lingga dan Marsono (2013) mengenai pemberian pupuk pada tanaman akan memberikan pengaruh terhadap pertumbuhan vegetatif dan generatif tanaman.

Pupuk kompos mempunyai kandungan unsur hara $\mathrm{N}$ yang mampu memacu pertumbuhan dan produksi tanaman unsur $\mathrm{N}$ diserap oleh tanaman melalui akar yang sangat berperan dalam proses fotosintesis dan pembentukan protein, lemak dan senyawa organik lainnya (Lingga dan Marsono, 2013). Protein tersebut memacu pembelahan sel. Pembelahan sel-sel tersebut membentuk suatu jaringan yang selanjutnya akan membentuk organ tanaman yaitu daun, batang, akar dan buah. Sesuai dengan tulisan Harjadi (2002), bahwa protein yang terbentuk pada sel-sel baru pada jaringan meristematik akan memacu proses pembelahan, pembesaran dan pemanjangan sel.

Rata-rata hasil tanaman secara berurutan menurut perlakuan $\mathrm{k} 0, \mathrm{k} 1, \mathrm{k} 2$ dan $\mathrm{k} 3$ yaitu sebanyak 272,63 g, 281,25 g, 342,50 g dan 375,21 g. Semakin ditingkatkan dosis diikuti dengan peningkatan hasil tanaman. Hasil tanaman mempunyai pengaruh diduga bahwa kandungan unsur hara $\mathrm{P}$ yang dimiliki pupuk kompos mampu mempengaruhi hasil tanaman dalam hal ini mampu mempengaruhi hasil tanaman cabai. Hal ini sesuai dengan tulisan Setyamidjaja (1986) dimana fosfor dapat memperbesar persentase pembentukan buah ditambahkan oleh Sutedjo (2008) bahwa secara umum fungsi $\mathrm{P}$ meningkatkan produksi.

Umur awal berbunga dan awal panen pada perlakuan pupuk kompos ini tidak berpengaruh nyata diduga bahwa paraemeter ini dipengaruh oleh faktor genetik tanaman dan lingkungan. Cabai varietas Bhaskara mempunyai deskripsi umur mulai berbunga pada umur 26-28 hst dan umur mulai panen pada 79-81 hst (Anonim, 2009). Rata-rata umur awal berbunga pada penelitian ini $22,83-23,67$ hst terjadi lebih cepat dari deskripsi tanaman cabai Bhaskara. Hal ini terjadi diduga karena faktor lingkungan. Menurut tulisan Winarso (2005) menyebutkan bahwa faktor genetik merupakan suatu ukuran baku suatu tanaman dan menentukan potensinya untuk tumbuh maksimal pada lingkungan pertumbuhan yang optimal. Ditambahkan oleh (Apoendi, 1991), bahwa pertumbuhan tanaman merupakan perpaduan antara susunan genetik dengan lingkungannya, sehingga respon terhadap lingkungan dapat mengganggu pertumbuhan.

Hasil catatan BMKG Temindung Samarinda selama penelitian berlangsung pada bulan Juli sampai dengan September tercatat curah hujan sejumlah $71,1 \mathrm{~mm} /$ bulan. Curah hujan ini tidak mencukupi kebutuhan tanaman yang sesuai dengan syarat tumbuh sebanyak 1.000-3.000 $\mathrm{mm} /$ tahun (Sarpian, 2007). Ditambahkan dari tulisan Munawar (2011) pada saat musim kemarau sebaik apapun sifat fisik, sifat kimia dan sifat biologi serta ketersediaan haranya, tanah tidak akan menghasilkan secara maksimal tanpa pengairan yang cukup.

Tabel 1. Pengaruh Pemberian Pupuk Kompos Dan Pupuk Green Tonik Terhadap Rata-Rata Tinggi Tanaman Umur 27 Hari Setelah Tanam $(\mathrm{cm})$

\begin{tabular}{cccccc}
\hline \multirow{2}{*}{ Pupuk Green Tonik } & \multicolumn{4}{c}{ Pupuk Kompos (k) } & \multirow{2}{*}{ Rata-rata } \\
\cline { 2 - 5 } & $\mathrm{k} 0$ & $\mathrm{k} 1$ & $\mathrm{k} 2$ & $\mathrm{k} 3$ & \\
\cline { 2 - 5 } g0 & 18,63 & 16,27 & 22,00 & 23,70 & $20,15 \mathrm{a}$ \\
g1 & 18,37 & 19,63 & 22,80 & 21,87 & $20,67 \mathrm{ab}$ \\
g2 & 20,63 & 22,43 & 23,03 & 23,67 & $22,44 \mathrm{c}$ \\
g3 & 23,93 & 24,30 & 25,73 & 25,23 & $24,80 \mathrm{~d}$ \\
\hline Rata-rata & $20,39 \mathrm{a}$ & $20,66 \mathrm{ab}$ & $23,39 \mathrm{c}$ & $23,62 \mathrm{c}$ & \\
\hline
\end{tabular}

Keterangan : Angka rata-rata yang diikuti huruf yang sama menunjukkan tidak berbeda nyata pada uji BNT $5 \%\left(\mathrm{BNT}_{\mathrm{g}}=1,38\right.$ dan $\left.\mathrm{BNT}_{\mathrm{k}}=1,38\right)$ 
Tabel 2. Pengaruh Pemberian Pupuk Kompos Dan Pupuk Green Tonik Terhadap Rata-Rata Tinggi Tanaman Umur 40 Hari Setelah Tanam $(\mathrm{cm})$

\begin{tabular}{cccccc}
\hline & \multicolumn{4}{c}{ Pupuk Kompos $(\mathrm{k})$} & \multirow{2}{*}{ Rata-rata } \\
\cline { 2 - 4 } Pupuk Green Tonik & $\mathrm{k} 0$ & $\mathrm{k} 1$ & $\mathrm{k} 2$ & $\mathrm{k} 3$ & \\
\cline { 2 - 5 } & \multicolumn{5}{c}{$\ldots \ldots \ldots \ldots \ldots \ldots \mathrm{cm} \ldots \ldots \ldots \ldots \ldots \ldots \ldots$} \\
\hline g0 & 39,43 & 41,03 & 44,33 & 43,80 & $42,15 \mathrm{a}$ \\
g1 & 41,10 & 41,73 & 42,87 & 46,67 & $43,09 \mathrm{ab}$ \\
g2 & 43,83 & 47,07 & 49,20 & 48,27 & $47,09 \mathrm{c}$ \\
g3 & 46,90 & 47,57 & 47,83 & 48,53 & $47,71 \mathrm{c}$ \\
\hline Rata-rata & $42,82 \mathrm{a}$ & $44,35 \mathrm{~b}$ & $46,06 \mathrm{c}$ & $46,82 \mathrm{c}$ & \\
\hline
\end{tabular}

Keterangan : Angka rata-rata yang diikuti huruf yang sama menunjukkan tidak berbeda nyata pada uji BNT $5 \%\left(\mathrm{BNT}_{\mathrm{g}}=1,25\right.$ dan $\left.\mathrm{BNT}_{\mathrm{k}}=1,25\right)$

Tabel 3. Pengaruh Pemberian Pupuk Kompos Dan Pupuk Green Tonik Terhadap Rata-Rata Tinggi Tanaman Umur 53 Hari Setelah Tanam (cm)

\begin{tabular}{cccccc}
\hline \multirow{2}{*}{\begin{tabular}{c} 
Pupuk Green Tonik \\
\cline { 2 - 5 } (g)
\end{tabular}} & \multicolumn{4}{c}{ Pupuk Kompos (k) } & \multirow{2}{*}{ Rata-rata } \\
\cline { 2 - 5 } & & $\mathrm{k} 1$ & $\mathrm{k} 2$ & $\mathrm{k} 3$ & \\
\hline $\mathrm{g} 0$ & 52,07 & 56,90 & 61,63 & 62,57 & $58,29 \mathrm{a}$ \\
$\mathrm{g} 1$ & 57,10 & 58,73 & 65,60 & 65,50 & $61,73 \mathrm{~b}$ \\
g2 & 60,67 & 68,80 & 65,70 & 70,90 & $66,52 \mathrm{c}$ \\
g3 & 72,53 & 67,17 & 70,70 & 74,03 & $71,1 \mathrm{~d}$ \\
\hline Rata-rata & $60,59 \mathrm{a}$ & $62,90 \mathrm{ab}$ & $65,91 \mathrm{c}$ & $68,25 \mathrm{c}$ & \\
\hline
\end{tabular}

Keterangan : Angka rata-rata yang diikuti huruf yang sama menunjukkan tidak berbeda nyata pada uji $\mathrm{BNT} 5 \%\left(\mathrm{BNT}_{\mathrm{g}}=2,94\right.$ dan $\left.\mathrm{BNT}_{\mathrm{k}}=2,94\right)$

Tabel 4. Pengaruh Pemberian Pupuk Kompos Dan Pupuk Green Tonik Terhadap Rata-Rata Diameter Batang Umur 27 Hari Setelah Tanam $(\mathrm{cm})$

\begin{tabular}{|c|c|c|c|c|c|}
\hline \multirow{2}{*}{ Pupuk Green Tonik } & \multicolumn{4}{|c|}{ Pupuk Kompos (k) } & \multirow{2}{*}{ Rata-rata } \\
\hline & $\mathrm{k} 0$ & $\mathrm{k} 1$ & $\mathrm{k} 2$ & $\mathrm{k} 3$ & \\
\hline & \multicolumn{5}{|c|}{. } \\
\hline g0 & 0,27 & 0,33 & 0,40 & 0,47 & $0,37 \mathrm{a}$ \\
\hline $\mathrm{g} 1$ & 0,27 & 0,33 & 0,47 & 0,47 & $0,38 \mathrm{ab}$ \\
\hline $\mathrm{g} 2$ & 0,43 & 0,43 & 0,63 & 0,60 & $0,53 \mathrm{c}$ \\
\hline g3 & 0,50 & 0,50 & 0,53 & 0,57 & $0,53 \mathrm{c}$ \\
\hline Rata-rata & $0,37 \mathrm{a}$ & $0,40 \mathrm{ab}$ & $0,51 \mathrm{c}$ & $0,53 \mathrm{c}$ & \\
\hline
\end{tabular}

Keterangan : Angka rata-rata yang diikuti huruf yang sama menunjukkan tidak berbeda nyata pada uji BNT $5 \%\left(\mathrm{BNT}_{\mathrm{g}}=0,10\right.$ dan $\left.\mathrm{BNT}_{\mathrm{k}}=0,10\right)$

Tabel 5. Pengaruh Pemberian Pupuk Kompos Dan Pupuk Green Tonik Terhadap Rata-Rata Diameter Batang Umur 40 Hari Setelah Tanam (cm)

\begin{tabular}{cccccc}
\hline \multirow{2}{*}{$\begin{array}{c}\text { Pupuk Green Tonik } \\
\text { (g) }\end{array}$} & \multicolumn{4}{c}{ Pupuk Kompos $(\mathrm{k})$} & \multirow{2}{*}{ Rata-rata } \\
\cline { 2 - 4 } & $\mathrm{k} 0$ & $\mathrm{k} 1$ & $\mathrm{k} 2$ & $\mathrm{k} 3$ & \\
\hline g0 & 0,27 & 0,33 & 0,40 & 0,47 & $0,56 \mathrm{a}$ \\
$\mathrm{g} 1$ & 0,27 & 0,33 & 0,47 & 0,47 & $0,65 \mathrm{~b}$ \\
g2 & 0,43 & 0,43 & 0,63 & 0,60 & $0,73 \mathrm{c}$ \\
g3 & 0,50 & 0,50 & 0,53 & 0,57 & $0,78 \mathrm{c}$ \\
\hline Rata-rata & $0,60 \mathrm{a}$ & $0,61 \mathrm{ab}$ & $0,73 \mathrm{c}$ & $0,77 \mathrm{c}$ & \\
\hline
\end{tabular}

Keterangan : Angka rata-rata yang diikuti huruf yang sama menunjukkan tidak berbeda nyata pada uji BNT $5 \%\left(\mathrm{BNT}_{\mathrm{g}}=0,10\right.$ dan $\left.\mathrm{BNT}_{\mathrm{k}}=0,10\right)$ 
Tabel 6. Pengaruh Pemberian Pupuk Kompos Dan Pupuk Green Tonik Terhadap Rata-Rata Diameter Batang Umur 53 Hari Setelah Tanam (cm)

\begin{tabular}{cccccc}
\hline \multirow{2}{*}{$\begin{array}{c}\text { Pupuk Green Tonik } \\
\text { (g) }\end{array}$} & \multicolumn{4}{c}{ Pupuk Kompos (k) } & \multirow{2}{*}{ Rata-rata } \\
\cline { 2 - 5 } & $\mathrm{k} 0$ & $\mathrm{k} 1$ & $\mathrm{k} 2$ & $\mathrm{k} 3$ & \\
\hline $\mathrm{g} 0$ & 0,50 & 0,60 & 0,73 & 0,80 & $0,66 \mathrm{a}$ \\
$\mathrm{g} 1$ & 0,77 & 0,73 & 0,97 & 0,93 & $0,85 \mathrm{~b}$ \\
$\mathrm{~g} 2$ & 0,97 & 1,00 & 1,03 & 1,10 & $1,03 \mathrm{c}$ \\
$\mathrm{g} 3$ & 1,07 & 1,00 & 1,10 & 1,13 & $1,08 \mathrm{c}$ \\
\hline Rata-rata & $0,83 \mathrm{a}$ & $0,83 \mathrm{ab}$ & $0,96 \mathrm{c}$ & $0,99 \mathrm{c}$ & \\
\hline
\end{tabular}

Keterangan : Angka rata-rata yang diikuti huruf yang sama menunjukkan tidak berbeda nyata pada uji BNT $5 \%\left(\mathrm{BNT}_{\mathrm{g}}=0,07\right.$ dan $\left.\mathrm{BNT}_{\mathrm{k}}=0,07\right)$

Tabel 7. Pengaruh Pemberian Pupuk Kompos Dan Pupuk Green Tonik Terhadap Rata-Rata Umur Awal Muncul Bunga Hari Setelah Tanam (hari)

\begin{tabular}{|c|c|c|c|c|c|}
\hline \multirow{3}{*}{$\begin{array}{l}\text { Pupuk Green Tonik } \\
\text { (g) }\end{array}$} & \multicolumn{4}{|c|}{ Pupuk Kompos (k) } & \multirow{2}{*}{ Rata-rata } \\
\hline & $\mathrm{k} 0$ & $\mathrm{k} 1$ & $\mathrm{k} 2$ & $\mathrm{k} 3$ & \\
\hline & \multicolumn{5}{|c|}{ 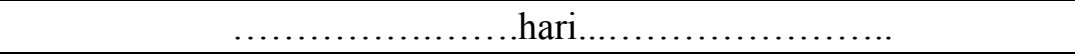 } \\
\hline g0 & 23,00 & 22,00 & 23,00 & 23,33 & 22,83 \\
\hline $\mathrm{g} 1$ & 23,33 & 23,00 & 23,67 & 23,00 & 23,25 \\
\hline g2 & 23,67 & 23,33 & 23,33 & 23,33 & 23,42 \\
\hline g3 & 23,00 & 23,33 & 23,33 & 23,00 & 23,17 \\
\hline Rata-rata & 23,25 & 22,92 & 23,33 & 23,17 & \\
\hline
\end{tabular}

Tabel 8. Pengaruh Pemberian Pupuk Kompos Dan Pupuk Green Tonik Terhadap Rata-Rata Umur Awal Panen Hari Setelah Tanam (hari)

\begin{tabular}{|c|c|c|c|c|c|}
\hline \multirow{3}{*}{$\begin{array}{l}\text { Pupuk Green Tonik } \\
\text { (g) }\end{array}$} & \multicolumn{4}{|c|}{ Pupuk Kompos (k) } & \multirow{2}{*}{ Rata-rata } \\
\hline & $\mathrm{k} 0$ & $\mathrm{k} 1$ & $\mathrm{k} 2$ & k3 & \\
\hline & \multicolumn{5}{|c|}{ f...................hari.......................... } \\
\hline g0 & 72,33 & 50,33 & 69,67 & 70,00 & 65,58 \\
\hline g1 & 66,67 & 69,67 & 73,67 & 69,67 & 69,92 \\
\hline g2 & 74,00 & 63,33 & 70,00 & 66,67 & 68,50 \\
\hline g3 & 69,67 & 63,67 & 66,67 & 68,67 & 67,17 \\
\hline Rata-rata & 70,67 & 61,75 & 70,00 & 68,75 & \\
\hline
\end{tabular}

Tabel 9. Pengaruh Pemberian Pupuk Kompos Dan Pupuk Green Tonik Terhadap Rata-Rata Berat Buah (gram)

\begin{tabular}{|c|c|c|c|c|c|}
\hline \multirow{3}{*}{$\begin{array}{l}\text { Pupuk Green Tonik } \\
\text { (g) }\end{array}$} & \multicolumn{4}{|c|}{ Pupuk Kompos (k) } & \multirow{2}{*}{ Rata-rata } \\
\hline & $\mathrm{k} 0$ & $\mathrm{k} 1$ & $\mathrm{k} 2$ & $\mathrm{k} 3$ & \\
\hline & \multicolumn{5}{|c|}{ 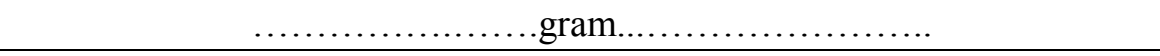 } \\
\hline g0 & 216,67 & 225,17 & 258,83 & 304,17 & $251,21 \mathrm{a}$ \\
\hline g1 & 221,83 & 212,50 & 218,83 & 372,33 & $256,38 \mathrm{ab}$ \\
\hline g2 & 291,50 & 357.00 & 433,33 & 366,83 & $362,17 \mathrm{c}$ \\
\hline g3 & 360,50 & 330,33 & 459,00 & 457,50 & $401,83 \mathrm{c}$ \\
\hline Rata-rata & $272,63 \mathrm{a}$ & $281,25 \mathrm{ab}$ & $342,50 \mathrm{c}$ & $375,21 \mathrm{c}$ & \\
\hline
\end{tabular}

Keterangan : Angka rata-rata yang diikuti huruf yang sama menunjukkan tidak berbeda nyata pada uji BNT $5 \%\left(\mathrm{BNT}_{\mathrm{g}}=53,80\right.$ dan $\left.\mathrm{BNT}_{\mathrm{k}}=53,80\right)$

\section{Pengaruh Pupuk Green Tonik}

Berdasarkan hasil sidik ragam perlakuan pupuk Green Tonik (g) menunjukkan bahwa berpengaruh sangat nyata terhadap rata-rata tinggi dan diameter tanaman pada umur 27 hari HST, 40 HST dan 53 HST serta rata-rata hasil tanaman. Namun tidak berpengaruh nyata 
terhadap umur awal muncul bunga dan waktu awal panen.

Rata-rata tinggi tanaman umur 27 hari HST, 40 HST dan 53 HST yang tertinggi pada perlakuan g3 secara berurutan menurut umur tanaman yaitu $24,80 \mathrm{~cm}, 47,71 \mathrm{~cm}$ dan $71,12 \mathrm{~cm}$ dan rata-rata tinggi terendah pada perlakuan g0 secara berurutan menurut umur tanaman yaitu $20,15 \mathrm{~cm}, 42,15 \mathrm{~cm}$ dan $58,29 \mathrm{~cm}$.

Perlakuan pupuk Green Tonik (g) sangat nyata berpengaruh terhadap rata-rata tinggi dan diameter tanaman pada umur 27 hari HST, 40 HST dan 53 HST serta rata-rata hasil tanaman. Kandungan unsur hara yang dikandung pupuk Green Tonik (g) memberikan pengaruh yang nyata terhadap fase vegetatif (tinggi tanaman dan diameter batang) dan fase generatif (hasil panen).

Pupuk Green Tonik mempunyai kandungan unsur hara yang digunakan dalam pertumbuhan tanaman baik tinggi maupun diameter tanaman. Hal ini diduga bahwa kandungan unsur hara yang dimiliki pupuk Green Tonik mampu menyuplai unsur hara yang dibutuhkan oleh tanaman. Suplai unsur hara yang cukup bagi tanaman akan mempengaruhi pertumbuhanan tanaman (Winarso, 2005). Pemberian pupuk Green Tonik melalui daun relatif lebih cepat diserap dan digunakan oleh tanaman hal ini diperkuat dengan tulisan Yuwono dan Rosmarkam (2013) bahwa pemberian pupuk melalui daun lebih cepat pengaruhnya terhadap tanaman.

Rata-rata hasil tanaman secara berurutan menurut perlakuan g0, g1, g2 dan g3 yaitu sebanyak 251,21 g, 256,38 g, 362,17 g dan 401,83 g. Semakin ditingkatkan dosis diikuti dengan peningkatan hasil tanaman. Hasil tanaman mengalami peningkatan seiring dengan peningkatan dosis. Hal ini diduga bahwa kebutuhan unsur hara yang diperlukan oleh tanaman mampu disuplai oleh pupuk Green Tonik dengan peningkatan dosis yang meningkatkan hasil tanaman melalui pemupukan melalui daun. Disebutkan dalam tulisan oleh Yuwono dan Rosmarkam (2013) peningkatan hasil yang tinggi dan sangat tinggi umumnya memerlukan tambahan pemupukan melalui pemupukan lewat daun baik unsur hara makro maupun unsur hara mikro.

Umur awal berbunga dan awal panen pada perlakuan pupuk kompos ini tidak berpengaruh nyata diduga bahwa paraemeter ini dipengaruh

\section{KESIMPULAN}

1. Perlakuan pupuk kompos (k) berpengaruh sangat nyata terhadap rata-rata tinggi dan oleh faktor genetik tanaman dan lingkungan. Cabai varietas Bhaskara mempunyai deskripsi umur mulai berbunga pada umur 26-28 hst dan umur mulai panen pada 79-81 hst (Anonim, 2009). Rata-rata umur awal berbunga pada penelitian ini 22,83 - 23,67 hst terjadi lebih cepat dari deskripsi tanaman cabai Bhaskara. Hal ini terjadi diduga karena faktor lingkungan. Menurut tulisan Winarso (2005) menyebutkan bahwa faktor genetik merupakan suatu ukuran baku suatu tanaman dan menentukan potensinya untuk tumbuh maksimal pada lingkungan pertumbuhan yang optimal. Ditambahkan oleh tulisan (Apoendi, 1991), bahwa pertumbuhan tanaman merupakan perpaduan antara susunan genetik dengan lingkungannya, sehingga respon terhadap lingkungan dapat mengganggu pertumbuhan.

Hasil catatan BMKG Temindung Samarinda selama penelitian berlangsung pada bulan Juli sampai dengan September tercatat curah hujan sejumlah $71,1 \mathrm{~mm} /$ bulan. Curah hujan ini tidak mencukupi kebutuhan tanaman yang sesuai dengan syarat tumbuh sebanyak 1.000-3.000 mm/ tahun (Sarpian, 2007). Selain itu juga dengan curah hujan yang rendah maka diikuti dengan suhu, lama penyinaran dan penguapan yang meningkat yang mengakibatkan terjadi penguapan pada saat pemberian pupuk Green Tonik. Penyerapan unsur hara tanaman melalui daun dipengaruhi salah satu berupa temperatur (Yuwono dan Rosmarkam, 2013).

\section{Interaksi Pupuk Kompos dan Pupuk Green Tonik}

Berdasarkan hasil sidik ragam menunjukkan bahwa pada interaksi kedua perlakuan yaitu pupuk kompos (k) dan pupuk Green Tonik (g) tidak berpengaruh nyata terhadap rata-rata semua parameter pengamatan. Hal ini dikarenakan antar kedua perlakuan tidak terdapat interaksi yang saling mempengaruhi satu sama lain dalam meningkatkan pertumbuhan tanaman, sehingga masing-masing perlakuan memberikan pengaruh secara terpisah. Hal ini sesuai dengan pendapat Stell dan Torrie (1993), bahwa apabila tidak terjadi atau tidak ditemukan adanya interaksi antara kedua faktor perlakuan, maka dapat dikatakan bahwa faktorfaktor tersebut bertindak bebas (independent) atau tidak tergantung satu sama lainnya.

diameter tanaman pada umur 27 hari HST, 40 HST dan 53 HST serta rata-rata berat buah, perlakuan terbaik pada taraf g2 (3 $\mathrm{ml} /$ liter air). 
2. Perlakuan pupuk Green Tonik (g) berpengaruh sangat nyata terhadap rata-rata tinggi dan diameter tanaman pada umur 27 hari HST, 40 HST dan 53 HST serta ratarata berat buah. perlakuan terbaik pada taraf $\mathrm{k} 2(100 \mathrm{~g} /$ polybag).

\section{DAFTAR PUSTAKA}

Anonim, 2008. Brosur Pupuk Green Tonik. CV. Yan Utama Carporation.

2009. Deskripsi Cabai Rawit Hibrida Varietas Bhaskara. PT. BISI INTERNATIONAL Tbk,Indonesia

. 2013. Samarinda Dalam Angka 2013. Bappeda Samarinda.

Apoendi, M. 1991. Pengantar Agronomi. Erlangga, Jakarta.

Hanafiah, K. A. 2005. Rancangan Percobaan Teori dan Aplikasi. Raja Grafindo Persada, Jakarta.

Hanafiah, K. A. 2007. Dasar - Dasar Ilmu Tanah. . Raja Grafindo Persada, Jakarta.

Harjadi, SS. 2002. Pengantar Agronomi. Gramedia Pustaka Utama. Jakarta.

Kaunang, W. B, Tuturoong. R. A. V, Londok, J. J. M. R dan Dewanto F. G. 2013. Pengaruh Pemupukan Anorganik dan Organik Terhadap Produksi Tanaman Jagung Sebagai Sumber Pakan. Jurnal Zootek ("Zootek", Jurnal) Vol; 32 No; 5 ISSN; 0852-2626.

Lingga, P. dan Marsono. 2013. Petunjuk Penggunaan Pupuk Edisi Revisi. Penebar Swadaya. Jakarta.
3. Interaksi perlakuan pupuk kompos (k) dan Green Tonik (g) tidak berpengaruh nyata terhadap semua parameter.

Munawar. A. 2011. Kesuburan Tanah dan Nutrisi Tanaman. IPB Press.Bogor.

Rukmana. 2006. Usaha Tani Cabai Rawit. Kanisius. Yogyakarta.

Sarpian, T. 2007. Bertanam Cabai Rawit Dalam Polybag. Penebar Swadaya. Jakarta.

Setyamidjaja, D. 1986. Pupuk dan Pemupukan. Simplex, Jakarta.

Steel, R. G. D. dan J. H. Torrie. 1993. Principles and Procedure of Statistic (Terjemahan B. Sumantri : Prinsip dan Prosedur Statistik). Gramedia, Jakarta.

Susila, A. D dan H. Luthfyrakhman. 2013. Optimasi Dosis Pupuk Anorganik dan Pupuk Kandang Ayam pada Budidaya Tomat Hibrida (Lycopersicum esculentumMill. L.). Bul. Agrohorti 1 (1) : 119 - 126 (2013).

Sutedjo, MM. 2002. Pupuk dan Cara Pemupukan. Rineka Cipta, Jakarta.

Sutedjo, M. M. 2008. Pupuk dan Cara Pemupukan. Rineka Cipta. Jakarta.

Winarso, S. 2005. Kesuburan Tanah Dasar Kesehatan dan Kualitas Tanah. Gava Media.Yogyakarta.

Wiryanta, B. T. 2012. Bertanam Cabai Rawit.Agromedia Pustaka. Jakarta Selatan.

Yuwono, N, W dan Rosmarkam, A. 2013. Ilmu Kesuburan Tanah. Kanisius. Yogyakarta. 